\title{
Chapter 5 \\ Wetlands in River Valleys as an Effect of Fluvial Processes and Anthropopression
}

\author{
Andrzej Strużyński, Leszek Książek, Wojciech Bartnik, \\ Artur Radecki-Pawlik, Karol Plesiński, Jacek Florek, \\ Maciej Wyrębek and Mateusz Strutyński
}

\begin{abstract}
The aim of the article is to show how the fluvial processes in rivers and their valleys can support wetland restoration activities. The exemplary objects were localized in the Upper Vistula Basin (Poland) and dealt with riverbed stability, channel capacity as well as revitalization of rivers with their valleys regarding wetland restoration. All of the mentioned parameters depend on the intensity of fluvial processes in rivers, especially meandering, anastomozing or braided. Rivers always tend to reach the state of hydrodynamical balance reflecting the actual river dynamics. The nature of channel transformation is quite complex. For example, the curvature of natural river increases proportionally to the transported load alimentation and inversely to the slope of the river. The human-modified rivers also tend to increase the curvature of their channels. Interestingly, all rivers create wetlands in the areas naturally connected to the main channel. Those wetlands are regularly watered by flood events. As a result, the areas with wetlands are a perfect natural environment for fauna and flora. River channels which are situated close to such an environment are also rich in fish and invertebrates. Wetlands in mountainous areas are rare or unique unlike in lowlands where they are more likely to be found. The channel incision reduce a possibility of wetland formation in the river valley, especially after bank enforcement. The presented case studies are the effect of different projects running by the Department of Water Engineering and Geotechnics, the University of Agriculture in Kraków on the rivers and streams: Vistula, Nida, Porębianka, Czarny Dunajec. These rivers differ in many aspects; however, each of the them is located in an area where wetlands or wetted areas are likely to appear. Among the described rivers are lowland and mountain rivers. Some of them are managed according to the European Water Framework Directive, i.e., in a close-to-nature manner.
\end{abstract}

Keywords River valley • Wetland • Morphological processes • River channel incision

\footnotetext{
A. Strużyński (凹) · L. Książek · W. Bartnik · A. Radecki-Pawlik · K. Plesiński ·

J. Florek · M. Wyrębek · M. Strutyński

Department of Hydraulics Engineering and Geotechnics, University of Agriculture

in Kraków, Al. Mickiewicza 24/28, 30-059 Kraków, Poland

e-mail: rmstruzy@cyf-kr.edu.pl

(C) The Author(s) 2015

S. Ignar and M. Grygoruk (eds.), Wetlands and Water Framework Directive,

GeoPlanet: Earth and Planetary Sciences, DOI 10.1007/978-3-319-13764-3_5
} 


\subsection{Introduction}

Fluvial processes are responsible for developing the actual morphological type of the river channels. Also wetlands found in the terraces are strictly dependent on the river flow regime. The water table connecting main channel and other branches or tributaries varies with the change of the water level. Dependably on the channel incision, land use or other factors, rivers can supply water or drain the terrace. Additionally during floods the intensification of different kinds of erosion or suffosion can appear so the river tends to create new channels or oxbow lakes. Aerial photographs or old maps often reveal the richness of the old channel system. A wide range of morphological structures in rivers and valleys is related to the hydrological and morphological parameters, the most important being: water flow and transported load alimentary, longitudinal slope, bed roughness and bed stability. Wetland ecosystems are part of quality elements for the classification of ecological status within the Water Frame Directive (WFD). While used to be localized in riparian zones, wetlands reflect the good hydromorphological characteristics of water bodies.

Going further, wetlands indicate the close to nature land use as inscribed in the advancement of the local community. From the end of the Second World War up to the early 90s, the Polish government did not pay particular attention to the issue of nature conservation, focusing on the intensification of industrial development or agricultural production instead. The WFD gives a new perspective for the development of local societies. The aim of the article is to stress the consequences of changed intensity of fluvial processes in rivers, their valleys and to analyse possibilities of wetland restoration within the guidelines of WFD but also under current land development. Even if the river training is done in these rivers, natural hydromorphological processes have to be taken into consideration during the decision making. While river ecosystems are strictly depended on the evaluation of these processes, artificial transformation of rivers and their valleys is often reckless. Technical river training and flood defence structures lead to narrowing of the river migration zone and disturb the hydraulic balance in the river channels. Serious problems grow during the intensification of the spatial development and many conflicts between floodplain capacity and human business appear. For this reason, even while needed, the restoration of wetlands in the river valleys is often relinquished. Reintroduction of wetlands in transformed river valleys would be connected to the change of human activities so the renaturization costs may often be unacceptable for the localities or connected to the elongated period of land-use transformation. 


\subsection{Case Study}

\subsubsection{Fluvial Processes in Natural Rivers}

Rivers always tend to develop a well balanced channel (Bartnik and Książek 2007; Bartnik et al. 2007; Książek et al. 2010). Even if there is a scarcity of the transported material, the adequate longitudinal and cross-section profiles of the river channel can be found (Korpak et al. 2009; Strużyński 2014; Wyżga et al. 2009). The curvature of natural rivers increases proportionally to the transported load alimentation and inversely to the slope of the river.

Mountainuous and lowland rivers differ in the flow dynamics as well as the intensity of fluvial processes. The sources of differences are connected to the retention and slopes of the basin but also to the size of transported material.

\section{Lowland Rivers}

Natural rivers modify their channels and valleys due to the fluvial processes appearing the whole year. The highest activity of the flowing water on channel creation appear with the quite low dominant flow which can be valued by the $\mathrm{Q}_{75 \%}$ (Leopold and Wolman 1957; Radecki-Pawlik 2011; Strużyński et al. 2013). These flows modify morphological parameters of the channel due to the bed and bank erosion or accumulation of bed material and contribute to the channel natural mobility (e.g., meandering, wandering) (Church 1992; Rosgen 1994). Dramatic channel transformations of river runs are very likely to occur during floods. According to the historical data gathered by Łajczak (2006b) on the Nida River, the multichannel system of lowland river can steadily change (Fig. 5.1).

Pictures describing the river system in the given years reveal the high hydromorphological dynamics. Such an activity is frequently recorded in alluvial channels. Two mechanisms may appear in lowland rivers during floods. One is creating

(a)

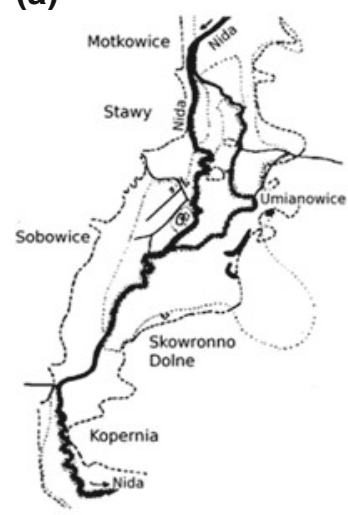

(b)

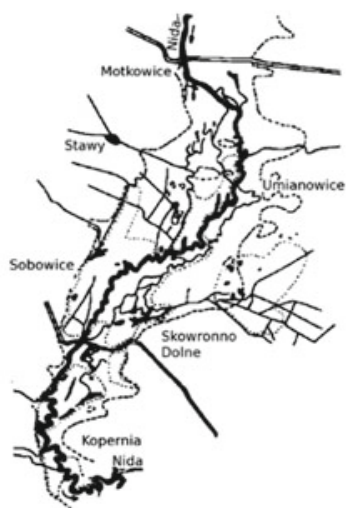

(c)

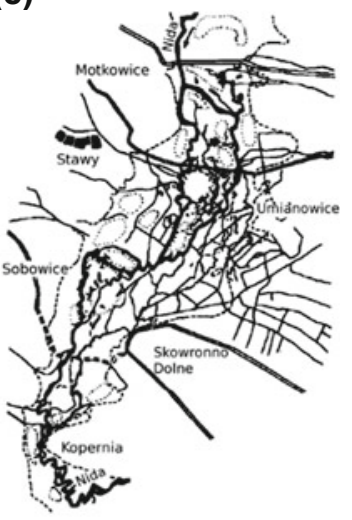

Fig. 5.1 Historical data show numerous changes of the Nida River morphology (after Łajczak 2006a). a 1839, b 1916, c 1938 
new branches and cutting off the old channels and the other is cutting off the meanders and creating oxbow lakes. Between the active river channel and the old channels, wetlands, bogs or fens may occur.

\section{Mountain Rivers}

The unaffected flow of the mountain rivers in their alluvial channels may naturally result in the formation of an incised channel, a stable channel or a channel dominated by accumulation (e.g., braided system). Stable and accumulation liable channels occupy the longest river segments with good conditions to form wetted areas or wetlands. Yet the most adequate conditions can be observed in alluvial parts of the rivers as they create the whole network of new branches and often shift main channels creating old ones (Gorczyca et al. 2011). While the bigger slope is the characteristic trait of mountain rivers as well as narrow valleys, wetlands are strictly connected with three factors, namely: the nature of fluvial processes taking place in the river channel (Strużyński 2014; Wyżga et al. 2010a), human and animal activity (Kłonowska-Olejnik and Radecki-Pawlik 2000), trees transported by the river current during floods (Wyżga and Zawiejska 2005; Faustini and Jones 2003; Radecki-Pawlik et al. 2011). Consequently, the incision of the mountain river channel may easily cause the disappearance of wet areas near the river channel.

\subsubsection{Fluvial Processes in Regulated Rivers}

Until the XXI century, rivers were regulated mostly with the technical methods. These trends led to narrowing and deepening of the river channels and narrowing of the flood channel. Main stream in regulated rivers had been forced to be as narrow as the bank enforcements. Within so-called hydraulically favourable channels, the flowing water reaches high energies during floods. However, it has to be remembered that even in regulated, straight channels, the fluvial processes exist. Such kind of regulations leads to the decrease of the transported material and to the appearance of the so-called "hungry rivers" in which bed degradation predominate. Regulated rivers cannot create wetlands, which finally tend to be degraded and used for human purposes. Bed incision processes caused the increase of channel capacity, so rivers started intensively drain their valleys.

\section{Lowland Rivers}

The process of meandering initiation is well recognized and found often in regulated rivers (Leopold and Wolman 1960; Kitanidis and Kennedy 1984) (Fig. 5.2). The thalweg movement is connected with the secondary currents. The same tendency can be observed in straight, regulated channels.

The aerial picture of the regulated lowland river, which is presented below, shows a distribution sand bars placed at an alternate angle (Fig. 5.3). This indicates non-homogeneous flow velocity distribution within the subsequent cross-sections. The presented riverbed forms move but sustain after frequent spring or summer floods. Regulated rivers are often separated from their valleys with the use of 


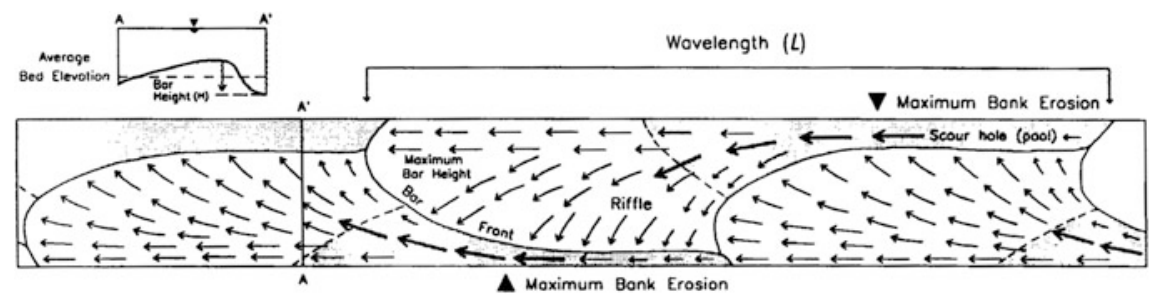

Fig. 5.2 The morphology of single-row alternate bars in straight channels with fortified banks (after Rhoads and Welford 1991)

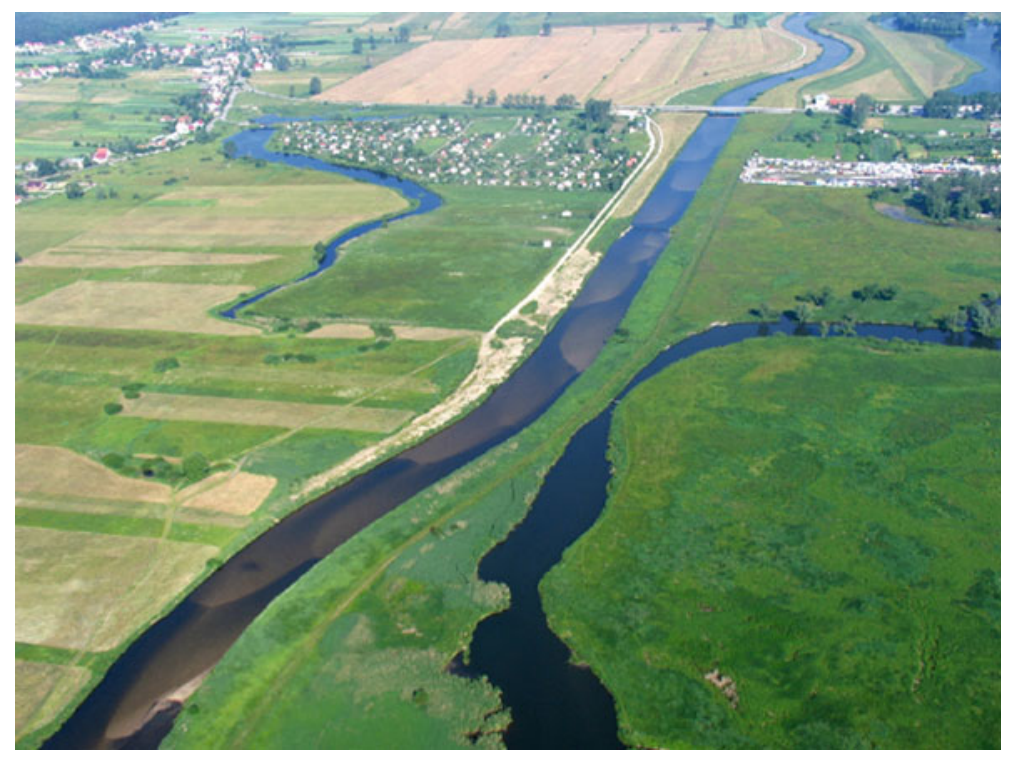

Fig. 5.3 Bedforms squeezed in a regulated channel (Source Pińczów Aero-club)

embankments (Łajczak 2006a). The banks of regulated rivers should receive proper maintenance as long as natural processes of river channel curving exist. Otherwise, the bank fortifications would be broken by floods allowing the river to regain the natural flow conditions.

\section{Mountain Rivers}

Check dams as well as step cascades are mainly used for technical regulation of mountain rivers. The aim of using check dams in the upper run of the streams is to halt excessive load from overburdening the river channel but this also consequences with the increase of the erosion processes in the downstream sections (Wyżga et al. 2008). For this reason, river fall corrections such as steps are introduced, adjusting hydrodynamic balance of the river through minimising load transportation ability. 


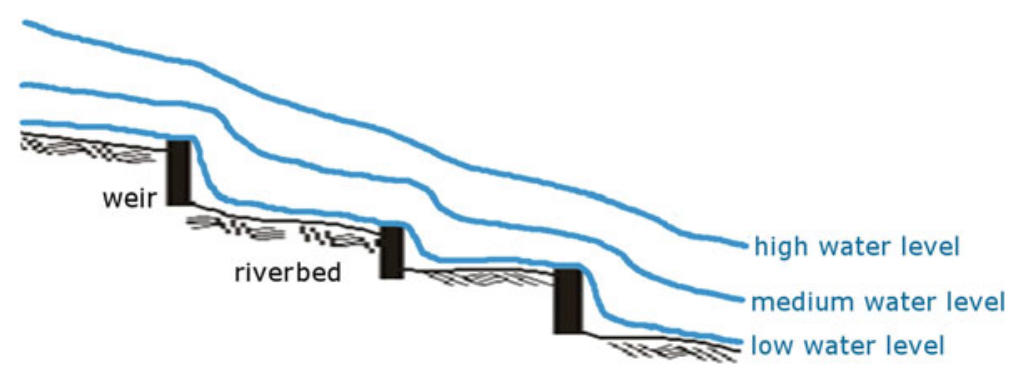

Fig. 5.4 The scheme of the regulated mountain river profile

As a result, the mountain rivers flow with a smaller slope in straight and slightly incised river channels (Fig. 5.4).

Apart from short periods of unusual floods, fluvial processes are "frozen" in these channels. High flows destroy the stable bed cover. However, these phenomena do exist and because of their violent nature they cause damage to river structures (Michalik et al. 1999; Książek, Michalik 2002). Therefore, the regulated watercourses need the periodic application of repair works. At present, the EU countries introduce the Water Frame Directive which creates favoured conditions to improve status of transformed water bodies. It is possible to employ bedload controlling dams instead of traditional check dams (Kopka 1998). Similarly, step cascades may be replaced by using special fish-penetrable structures. These structures ensure the stability of watercourses but simultaneously improve the hydromorphological parameters as well as restore the ecological corridor function of rivers.

\subsection{Description of the Research Areas}

Wetland restoration reconnaissance was performed in the Upper Vistula Basin (Poland) within the few projects running by the Department of Water Engineering and Geotechnics, the University of Agriculture in Kraków. The examples of performed in situ measurements are presented within the order: (a) the Vistula River near the town of Sandomierz, (b) the Nida River between the village of Rębów and the Pińczów town, (c) the Porębianka Stream in the near outlet sections (Mszana Dolna district), (d) the Czarny Dunajec River at the natural reach in the town of Wróblówka. Although the regarded river reaches differ in many aspects (Table 5.1), they are all located in areas of possible wetland appearance.

The Vistula River

The Vistula River is planned to become a waterway. For this reason the reach near Sandomierz (Fig. 5.5) is embanked and regulated by groins. Flood corridor within 
Table 5.1 Parameters of investigated river sections

\begin{tabular}{l|l|l|l|l}
\hline River & Nida & Vistula & $\begin{array}{l}\text { Czarny Dunajec } \\
\text { (Kojsówka) }\end{array}$ & Porębianka \\
\hline Type & Lowland & Lowland & Highland & Highland \\
\hline Reach length $(\mathrm{km})$ & $\begin{array}{l}6.4 \\
(18.8)\end{array}$ & 5 & 1.5 & 3 \\
\hline Subbasin area $\left(\mathrm{km}^{2}\right)$ & 3,352 & 31,810 & 93.7 & 72 \\
\hline Slope or the reach $(-)$ & 0.00073 & 0.00017 & 0.0068 & 0.0125 \\
\hline Mean diameter, $\mathrm{d}_{\mathrm{m}}(\mathrm{m})$ & 0.00058 & 0.0005 & - & 0.088 \\
\hline $\mathrm{d}_{90 \%}(\mathrm{~m})$ & 0.00105 & 0.0015 & - & 0.142 \\
\hline $\begin{array}{l}\text { Flow discharge } \mathrm{Q}_{50 \%} \\
\left(\mathrm{~m}^{3} \mathrm{~s}^{-1}\right)\end{array}$ & 150 & 1,832 & 53.13 (Koniówka) & 27 \\
\hline $\mathrm{Q}_{1 \%}$ & 450 & 7,338 & 252.63 (Koniówka) & 191 \\
\hline
\end{tabular}

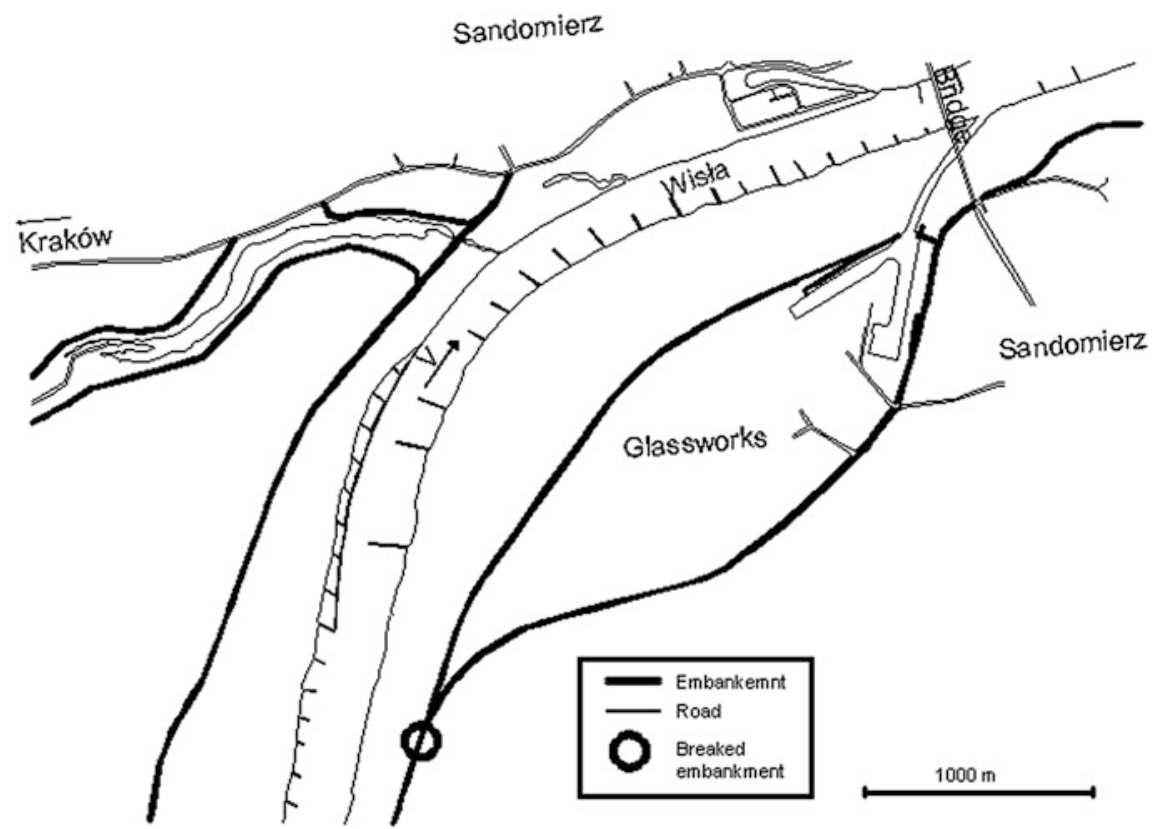

Fig. 5.5 Vistula River in the vicinity of the town Sandomierz

the upper Vistula is narrow. The nearby hills but also terraces are used for fruit production (mainly apples) (Bartnik and Książek 2011; Bartnik et al. 2011).

The right terrace lies currently outside the embankments which were broken during the 2010 spring flood (Bartnik and Książek 2011; Maciejewski et al. 2011). In that spring, flowing water (in May and June) with the peak discharge of $5,270 \mathrm{~m}^{3} \mathrm{~s}^{-1}$ outlined the inundation range up to $8.5 \mathrm{~km}$ reaching the embankments of the Łęg River. This flood fitted the borders made by the city of Tarnobrzeg and 
the local villages: Żupawa, Poręby Furmańskie and Gorzyce. Floods indicate that retention areas are too small within the reach of Sandomierz but also in the upstream reaches. While the flood passes the reach with unnaturally high water levels, congested embankments may easily brake. In these cases, inundation was much bigger than expected, appearing as a water retention area of an exceptional importance retention area. At present, the Vistula river flows in the incised channel. This river, however, had favoured the wetland creation due to high frequency of floods as well as impermeable substratum with hight content of organic matter created by inundations. In spite of the fact that the embankments between Kraków and Sandomierz were finalized in the 1920s, there are still oxbow lakes found upstream Sandomierz (Lajczak 2014). After regulation works, fauna and flora still treat the Vistula River as a green corridor. There are environmental protection areas established within the presented reach of the Vistula River and its valley: the Pieprzowe Mountains Nature Park, Nature 2,000 habitat protection area (the Tarnobrzeska Valley of the Vistula River-PLH 18,049), Nature 2,000 habitat protection area (the Pieprzowe Mountains-PLH 260,022) (Source http://geoserwis. gdos.gov.pl/mapy/).

\section{The Nida River}

The investigated reach of the Nida River is located between the village of Rębów and the town of Pińczów. This lowland river-the left tributary of the Vistula Rivercan be predominantly regarded as close to nature. Flowing through the central part of Poland it had created in its middle run an "inland delta", a unique multichannel system with numerous wetlands (Fig. 5.6).

The regulation works done in the 1980s become an example of unnecessary and wrong management of the river valley. Spring floods are characteristic for this river. Nida floods its valley every 3-5 years. Additionally, during inundations the embankments are often broken and the "middle delta" stays underwater for a few days (Strużyński 2006). These facts force the local community to adjust their agricultural habits to the existing flow regime. Thanks to this, the main objects found in the Nida river and valley are: regulated channel, oxbow lakes, old channels, wetlands, bogs and grasslands. Besides the Nida itself, there are more water sources in this region: Hajdaszek, Branka and stream from the village of Stawy. Hajdaszek is currently redirected by the local community to the Smuga Umianowicka stream, the Old Nida branch, whose channel bottom is localized lower than the Old Nida branch and drains the valley, which results in marching processes in the middle part of the valley. Branka, the left Nida tributary, flows currently across the valley directly to the regulated Nida channel. In the past the stream supplied left branch of the river called Old Nida (Smuga Umianowicka) in the neighbourhood of the village of Skowronno Górne. The stream flowing from the village of Stawy goes into the old branch near Sobowice village.

The Old Nida system (oxbow lakes or channels supplied currently by Nida tributaries) is characterized by smaller channels of the width ranging from 8 to $15 \mathrm{~m}$. The slope and curvature are responsible in this reach for intensive bedload 


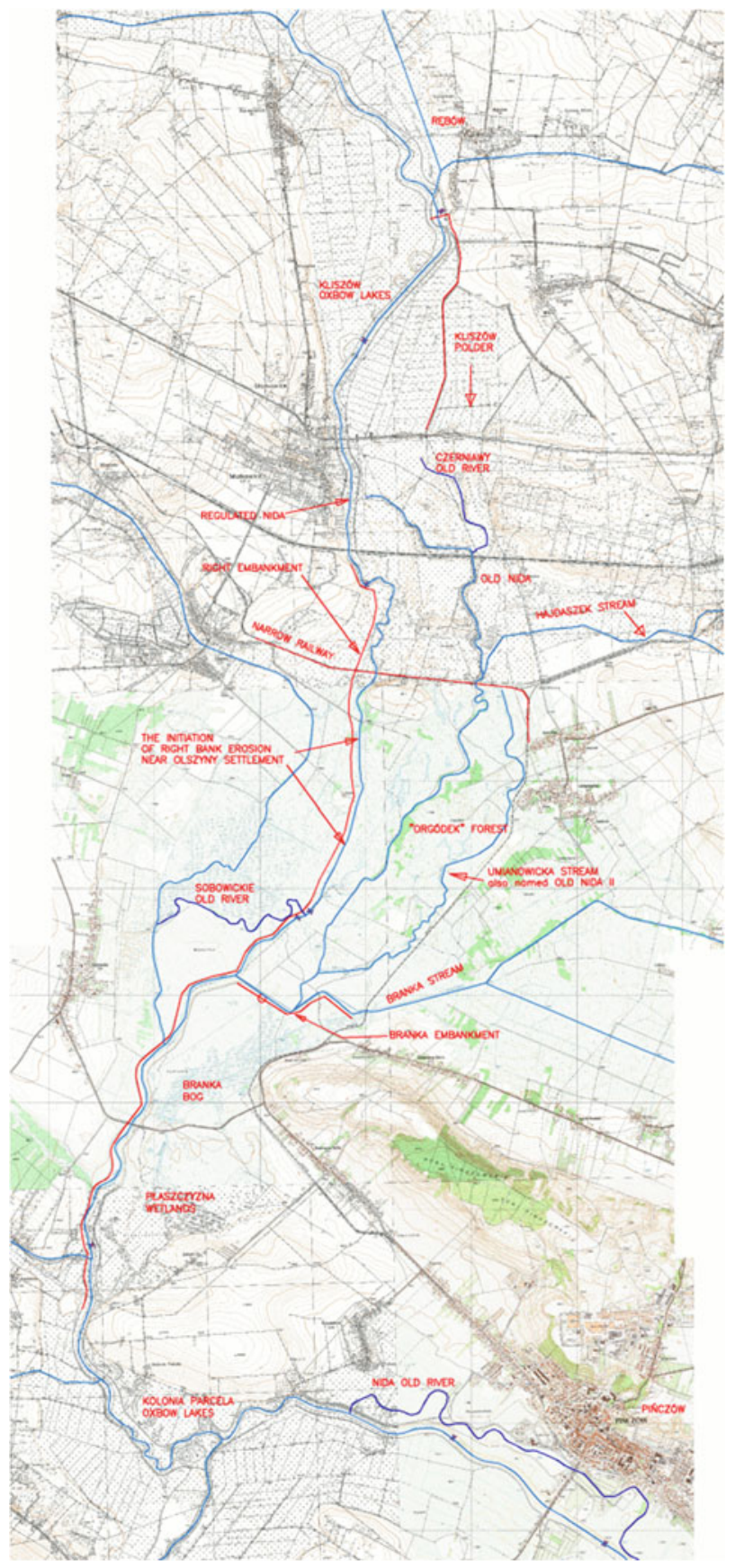

Fig. 5.6 The "middle delta" and its morphological objects 


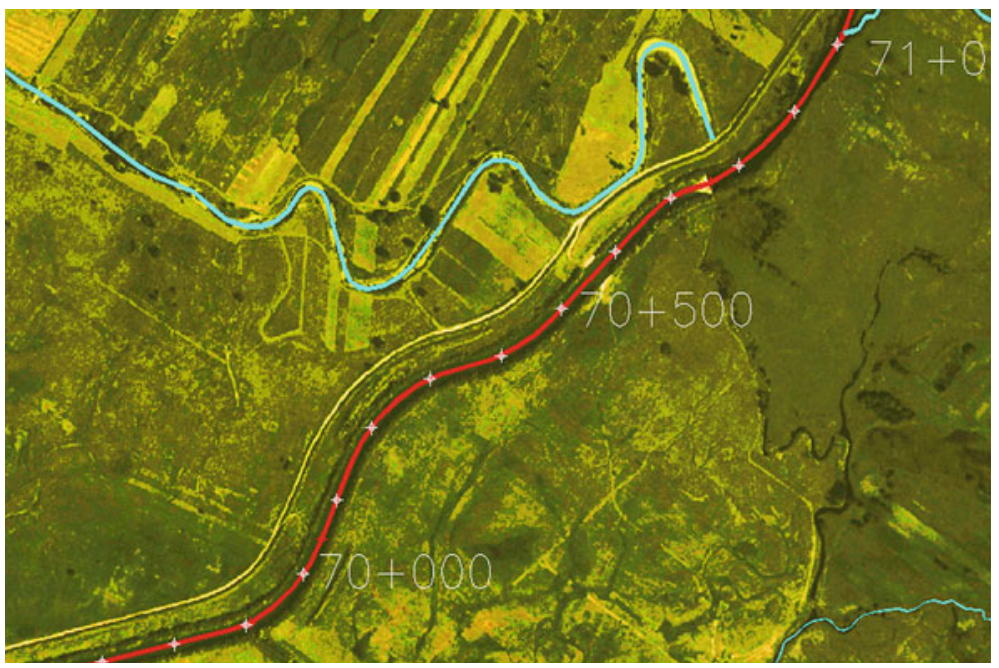

Fig. 5.7 The curvature comparison of the natural (blue) and regulated (red) river channel

Table 5.2 Expected change of parameters characterizing the river channel flow and the floodplain inundation

\begin{tabular}{l|l|l|l|l|l}
\hline Parameter & $\begin{array}{l}\text { River } \\
\text { width }(\mathrm{m})\end{array}$ & $\begin{array}{l}\text { River } \\
\text { depth }(\mathrm{m})\end{array}$ & $\begin{array}{l}\text { Flooded area } \\
(\mathrm{Q} 1 \%) \\
\left(\mathrm{mln} \mathrm{m}^{2}\right)\end{array}$ & $\begin{array}{l}\text { Valley capac- } \\
\text { ity }(\mathrm{Q} 1 \%) \\
\left(\mathrm{mln} \mathrm{m}^{3}\right)\end{array}$ & $\begin{array}{l}\text { Water depth in the } \\
\text { valley during flood } \\
(\mathrm{Q} 1 \%)(\mathrm{m})\end{array}$ \\
\hline $\begin{array}{l}\text { Current } \\
\text { state }\end{array}$ & 25 & 0.6 & 7.6 & 4.7 & 1.2 \\
\hline $\begin{array}{l}\text { After } \\
\text { restoration }\end{array}$ & $14-50$ & $0.4-0.8$ & 11.2 & 8.7 & 0.8 \\
\hline
\end{tabular}

transportation and instability of the bed during flood events. The curvature of the natural channel differs dramatically in comparison to the regulated ones (Fig. 5.7).

The multichannel system is well developed. To provide calculations of the flow distribution within the modified or restored river channels, the HEC-RAS calculation has been performed. The parameters of regulated and restored river channels are gathered in Table 5.2.

The comparison of width and depth of the Nida branches shows that the expected width of the natural bed is about $34 \mathrm{~m}$ and the depth should vary from 0.5 to $1 \mathrm{~m}$.

As long as the river was natural within the broader valley, it used to redistribute water periodically within the different parts of "delta". The restoration works should start from rebuilding proper connections between the old channels as well as initiating the water redistribution within the whole channel system. There is no certainty that on the sandy substratum of the valley the infiltrated water could be limited to the acceptable level. In the past within the "delta" region Nida had naturally hold one or two main channels (Fig. 5.1). For this reason, only part of the 
discharge from the main stream should be directed to the Old Nida channel. For better watering of the valley, the surrounding streams should also be used to supply the old channel system and the wetlands in the valley (Bartnik et al. 2004a, b, c).

At present, some species have disappeared from this region. Fortunately, the purpose of the intensification of agriculture production has been changed and the restoration of the old water system can be done. Another good example is the reservoir in Pińczów in which 5 species of molluscs live, including two which have been listed in the "red book of extinct species". The fauna and flora is not limited to molluscs in the Pińczowski Reservoir. In the widened valley, 262 kinds of plants, 51 mollusc, 11 amphibians, 3 reptiles, 160 birds and 16 mammals have been recognised (Bartnik et al. 2004a). Within the presented reach of the Nida River and the valley, the following protected areas had been established:

- National Landscape Parks (Zespół Świętokrzyskich i Nadnidziańskich Parków Krajobrazowych-National Landscape Park of the Valley of the Nida River),

- Nature 2,000 bird directive (Dolina Nidy-PLB260001),

- Nature 2,000 habitat directive (Ostoja Nidziańska PLH260003).

\section{The Porębianka River}

The Porębianka River is located in the southern part of Poland in the Gorce Mountains. It is a left tributary of the Mszanka River. Its source lies in the Obidowa Hill (1,000 $\mathrm{m}$ a.s.l.). Porębianka is a regulated river. In its upper run the valley is quite narrow and the river structures in the channel are distributed regularly. Bed material has been settled there but below this reach the lack of bedload has been encounted. Within the middle reach in village of Niedźwiedź, from the bridge down

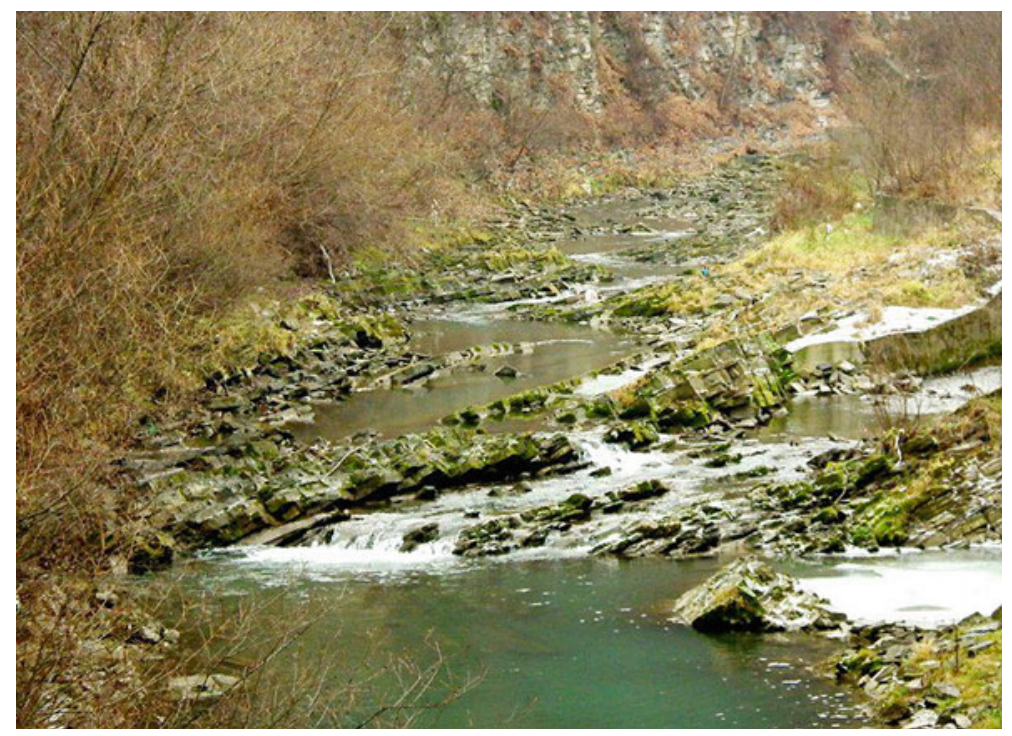

Fig. 5.8 Bedrock channel of the Porębianka River in the region of a local hydropower plant 


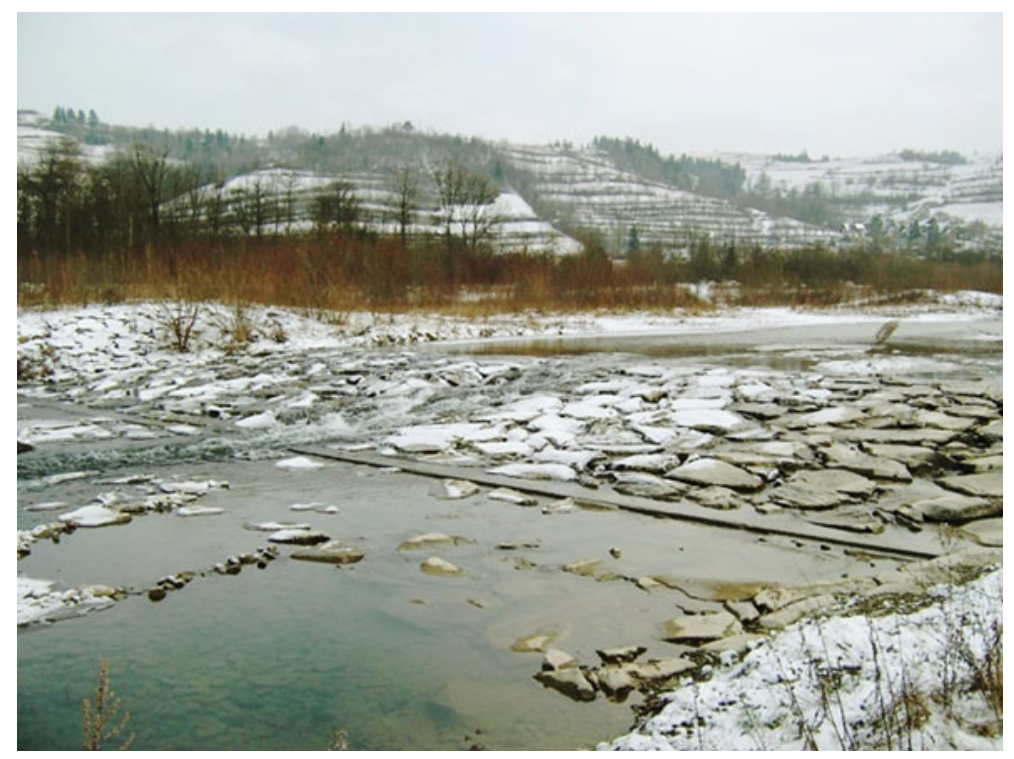

Fig. 5.9 Ramp - close to nature structure used in mountain rivers

to the RHS regulated reach, the rocky bed had been developed (Fig. 5.8) (Krzemien 1976, 1984; Radecki-Pawlik et al. 2010, 2013; Plesiński et al. 2013).

In this middle run, the river passes also two high steps damming up water for the power plant. The Porębianka in the lower run used to be a braided river but now its channel has been regulated by 25 ramps (rapid hydraulic structures, RHS, Fig. 5.9). After introducing ramps, the channel has straightened and had changed its morphodynamics. As long as floods passing this river are violent, the rapid hydraulic structures will demand periodic reparations.

\section{The Czarny Dunajec River}

Czarny Dunajec has its sources in the Tatra mountains. The river joins the Biały Dunajec River in the city of Nowy Targ, creating the Dunajec River. The flow dynamics of the Czarny Dunajec River is high. Nearly the whole area between the village of Podczerwone and the town of Nowy Targ is regulated with step correction and bank fortifications. Below the village of Wróblówka, there is only one, approximately $4 \mathrm{~km}$-long segment of the river in which the channel is not regulated, preserving original character. In the highest two-and-a-half-kilometre-long reach the Czarny Dunajec River is braided and downstream it changes to island-braided (Wyżga et al. 2010b). In the above-mentioned part, the river creates complex bends which mark the migration zone of about $400 \mathrm{~m}$ width. There are numerous areas where the terrain is wetted as localized lower (Fig. 5.10). The whole valley is covered with abundant flora. Away from the course, in inundation terraces, there are fields used for agricultural purposes. The area of the river and the valley is protected 


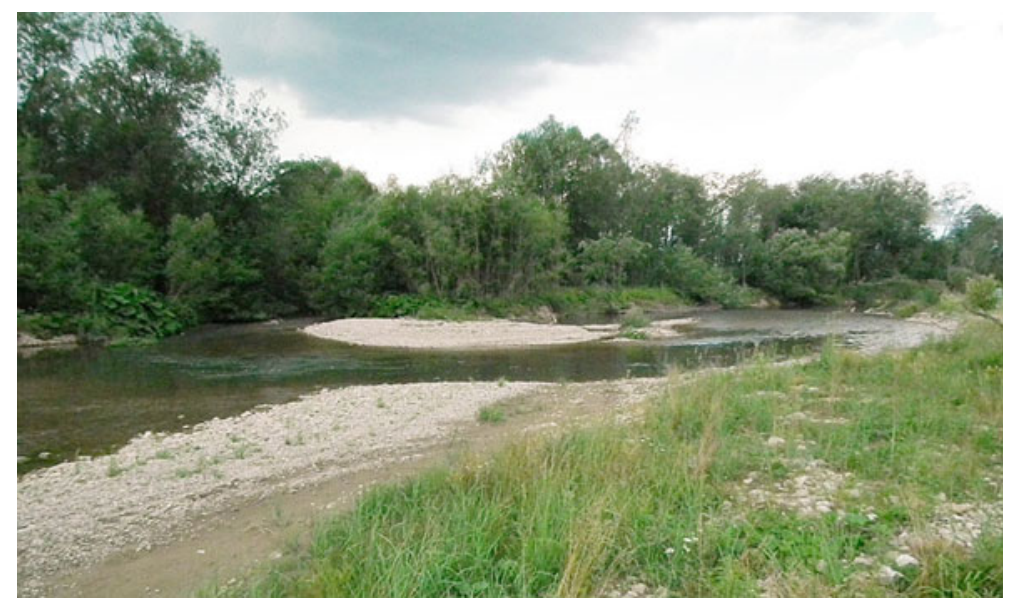

Fig. 5.10 The Czarny Dunajec River in the village of Wróblówka

by:- South Małopolska Protected Landscape Area,--Nature 2,000 bird directive (Torfowiska Orawsko-Nowotarskie-PLB12,0007),-Nature 2,000 habitat directive (Torfowiska Orawsko-Nowotarskie-PLH120016).

\subsection{Evidence of Wetlands in the Investigated Areas}

Presently no wetlands can be found in the valley of the Vistula River near Sandomierz (Lajczak 2006b), however numerous meander-shaped terrain forms remain there (Fig. 5.11). Terraces of Vistula river are made of muds and chernozems at a distance from 1 to $6 \mathrm{~km}$ from the river channel. This area used to be covered by wetlands. Upstream of Sandomierz, on both terraces, the oxbow lakes and the overgrown lakes exist. In Fig. 5.11 it is indicated that presently many of the well visible bars are forming, which indicates high fluvial activity within the channel of the Vistula River (Fig. 5.11, left-middle part of the picture). This shows that within this reach the transported material can settle outside the current.

Forces connected to secondary current are responsible for creating channel or alternate bars. They probably do not fit the channel run after it was poorly designed or there is no hydraulic balance between fluvial forces and critical forces characterizing movement of bed material. This trend should exist in regulated rivers. As long as Vistula tends to create meanders, the possibility of refreshing wetlands is real. At present the process of restoring wetlands can be started from the network of channels refreshing the existing oxbow lakes.

At present, the Nida River is an example where natural and regulated channels can be found in the nearby area (Fig. 5.12). Currently there are two main old channels in the valley (Fig. 5.6). One is the Old Nida, and the other is the Umianowicka Stream 


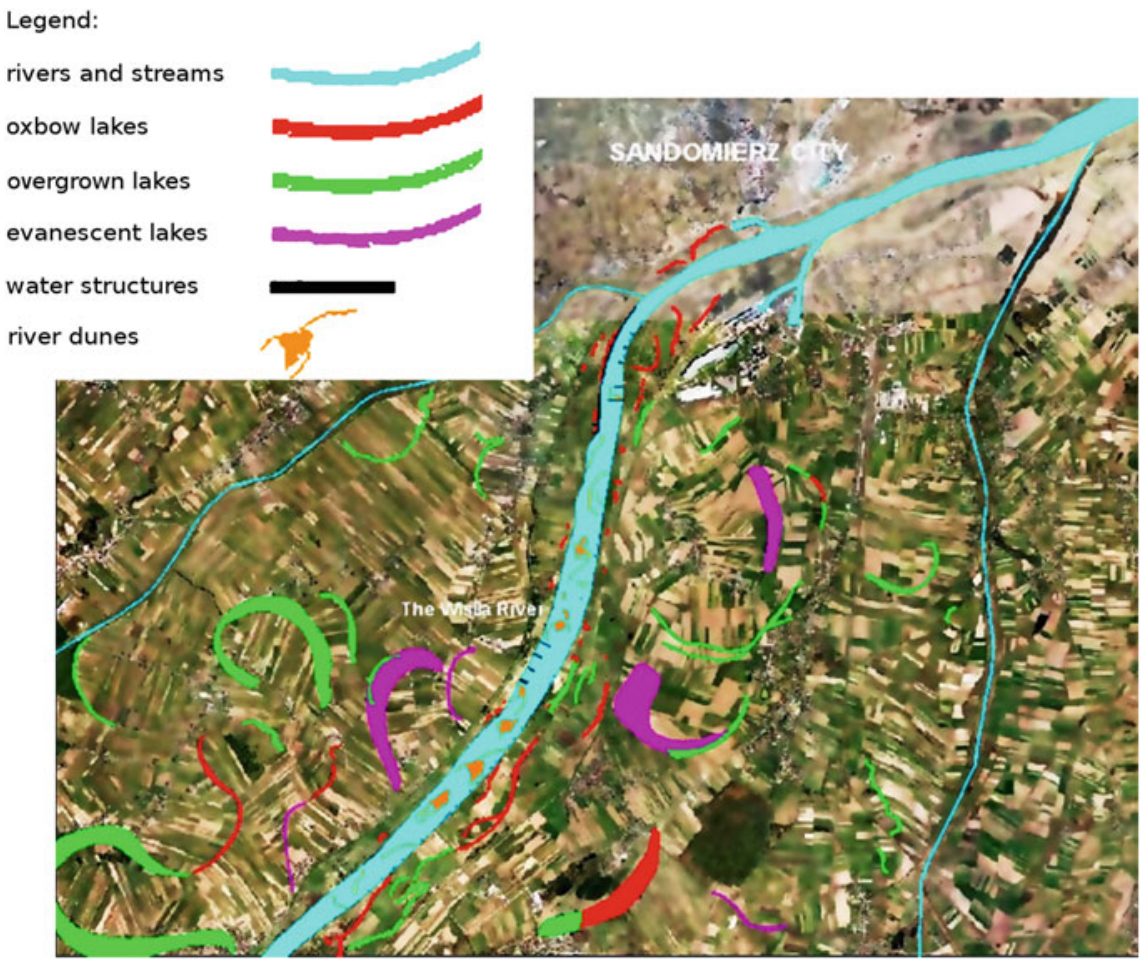

Fig. 5.11 Oxbow lakes and other channel-shape forms within the Vistula River natural migration zone (objects drawn on the satellite image. Source geoportal.gov.pl)

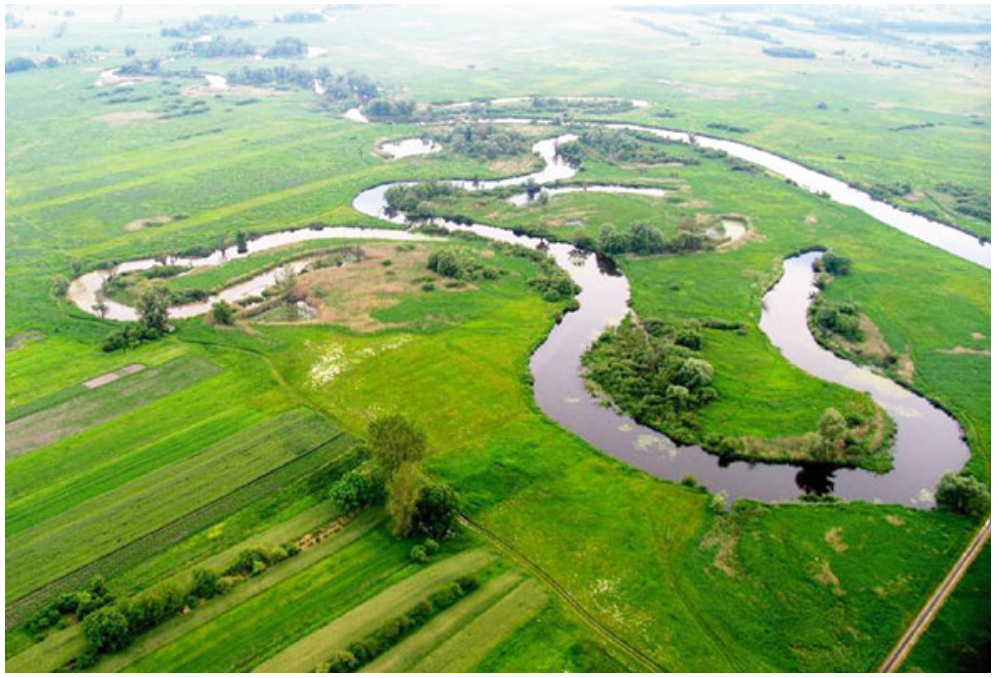

Fig. 5.12 Oxbow lakes surrounding the regulated reach of the Nida River in Pińczów (photo Aeroklub Pińczów) 


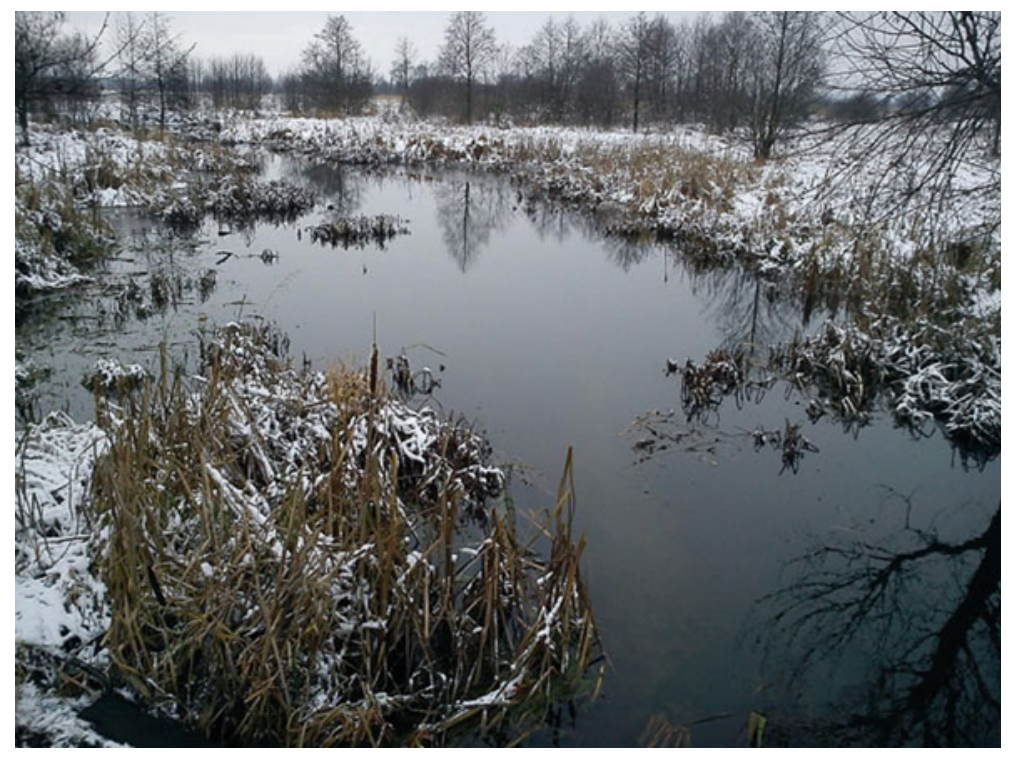

Fig. 5.13 The Nida's old river channel during winter

named also the Old Eastern Nida or the Old Nida II. Numerous oxbow lakes and wetlands still exist in the neighbourhood of these channels. Close to the village of Sobowice another active old channel of the Nida is located. In the region of the narrowed valley, the wetland ("Branka bog") created currently by the water flowing in the Branka stream exists. Another hill encroach into the Nida river valley in the neighbourhood of the settlement Kopernia creates conditions for the Płaszczyzna wetlands to exist. Downstream, close to the regulated river, the oxbow lakes are localized. Below of the road bridge and between villages Skowronno and Sobowice the oxbow lakes are left after river training both on the left and the right terrace.

When planning renaturalisation projects in the "middle delta", it should be taken into consideration that there are still many rare species of fauna and flora living in the valley (Strużyński 2011). On the other hand, some parts of the river valley are still cultivated or used as grazing lands. Consequently, renaturalisation projects should deal with all of the mentioned problems, i.e.: take into account the safety of the passing floods, increase the riverbed stability, restore natural flow conditions in the regulated channel and in the old channels, as well as to improve the ecological state of the whole system (Bartnik et al. 2013). The work should start from redistribution of water flowing trough the whole system existing in the "middle delta" (Fig. 5.13).

As Porębianka used to create braided channel, there were no wetlands in this valley but only wetted areas connected to the migration zone of the river. In a mountain region within such areas, high biodiversity can be found. After Korpak (2007) it can be stated unfortunately that between 1975 and 2005 the incised part of 


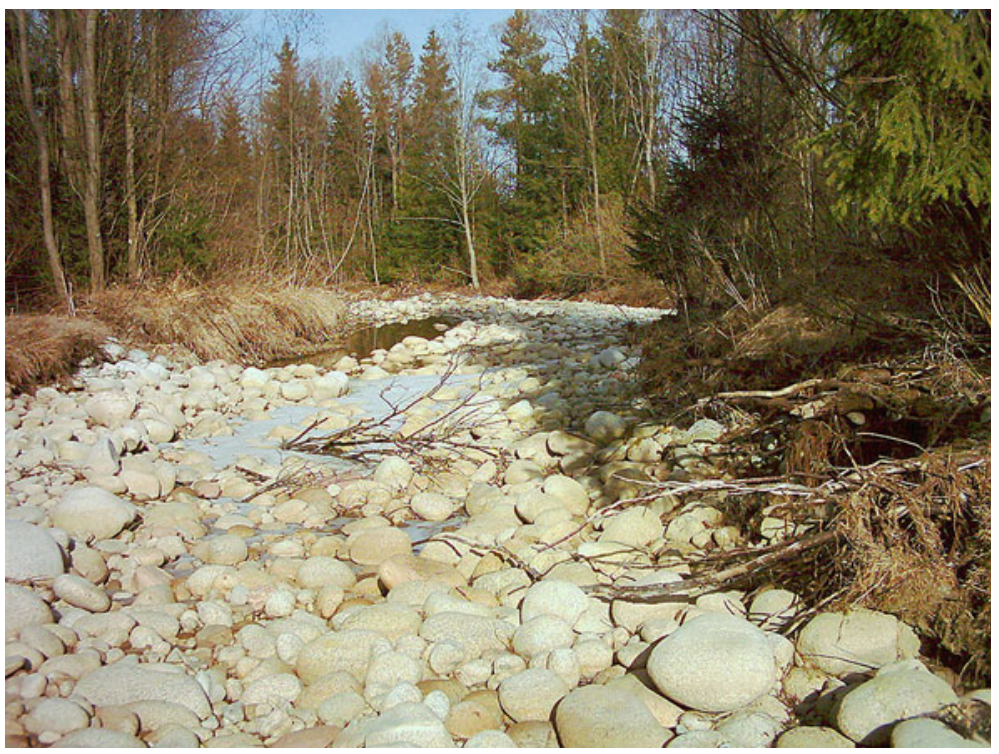

Fig. 5.14 Example of old channel "penetrating" the floodplain (Białka river)

the Porębianka stream channel had increased from 47 to $62 \%$. Currently the migration zone of the ramp regulated river reaches 50-60 m and the channel width varies from 25 to $30 \mathrm{~m}$. Before regulation works it used to be in the range of 70-150 m. One of the last braided rivers in Polish Carpathians is Białka river in the reach from the Krempachy gorge to its outlet. This river, close to nature, still develops multichannel system in the width of 100-250 m (Struzynski et al. 2011). Additional channel of braided river can penetrate the floodplain, locally indicating the water-table (Fig. 5.14). Within such ponds, many species can pass the larval period (i.e., macrozoobenthos, tadpoles). Within lower run of Porębianka stream there is still a possibility of restoring similar areas. One of the mechanisms which could intensify the morphological transformations is the bedload transport. Braided rivers are heavily loaded by this material. Unfortunately, within the upper sections of the stream, heavy regulation works were performed, blocking the sediment supply.

The Czarny Dunajec River within the mentioned reach flows between regulates sections. This influences the fluvial processes which transform the river from curvy to a braided river and closer to the town of Nowy Targ an island-braided channel. Through the braided part, the Nature 2,000 areas cross the valley from its left to the right side. Within the valley, multiple marks of the land-transformed oxbow lakes can be found. The incision of the riverbed exceeds $1.5 \mathrm{~m}$ (Fig. 5.15).

This signifies that erosion processes are still taking place, however the bedrock has not been reached yet and the braided character of the Czarny Dunajec River is still preserved. The main danger for this reach is the exploitation of the bed material 


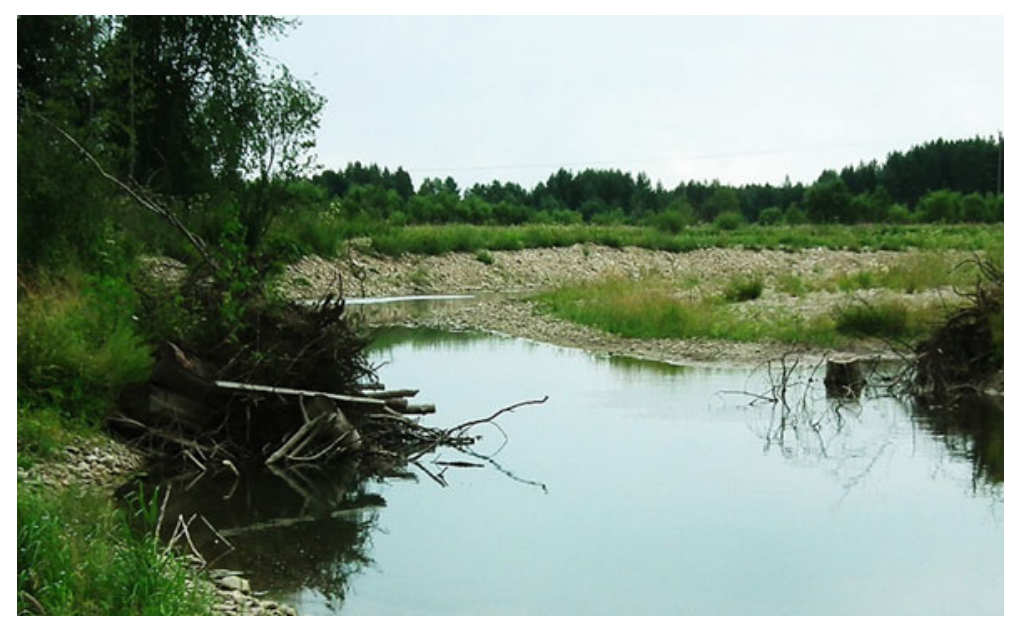

Fig. 5.15 The riverbed incision of the braided reach of the Czarny Dunajec

and a limited supply of the material from the regulated upper sections of the Czarny Dunajec River.

\subsection{Conclusions}

Human changes in fluvial processes are very complex. This results in difficulty of restoring the natural river morphology. Probably the worst are caused by narrowing of river migration zone. When river cannot erode banks and create new branches, the only way to get material for transportation is bed erosion. This is directly connected to the incision processes. Incised river cannot create wetlands.

At a short distance from the town of Sandomierz, the Vistula River had formed meanders which are nowadays in the process of land-transformation. The river is embanked and does not form new hydromorphological structures on the inundation terraces. The reasons of embankment creation were the flood disasters in XIX and XX centuries. During river training, the environmentally precious areas were cutoff. The reason of the agricultural as well as industrial development on the surroundings of the town of Sandomierz where very good soils created by the permanent water logging. The floods, however, encounter negative implications of human accommodation within the river migration zone. While those areas are highly investigated for agricultural use, it might be not easy to restore oxbow lakes or wetlands there. The Water Framework Directive, however, favours restoring of the environment. This is partially still possible. Further development within this area can be designed as sustainable, including works with purposes to refresh existing oxbow lakes with the use of water from local streams or from Vistula itself. 
Additionally, while restoring the waterway, many investigations accompanying the restoration could be done.

The Nida River basically flows across the close to nature, cultural landscape. The area of the widened valley, commonly referred to as "the middle delta", was once very attractive for its morphological structure and fluvial activity, not to mention a great diversity of ecosystem. At present, the area requires serious restoration after introducing unnecessary river-regulating works. The system of the cut-off channels is still recognizable and may well be recreated. Nida, however, used to be very morphologically active, creating new branches and oxbow lakes. After river training, the main channel had been stabilized. The old channels slowly dry and their vulnerable surroundings loose the environmental meaning. Even if some areas are used as grasslands, the dynamics of the river system should be restored. This could be initiated by irrigating the old channels and recurving the regulated river. The system then could slowly rebuild the reach and environmentally precious wetland system.

Porębianka flows in the lower run over the RHS's. The migration zone is decreased there by about $50 \%$, but ramp construction lets the bed material to overcome them and to create bars in this river. Currently the best solution for Porębianka river is to limit the human expansion within the river migration zone and to rebuild the river training system in the middle run in villages of Czarna Poręba and Niedźwiedź form weirs to RHS's. The increase of bedload rate would positively change the flood capacity of the channel. Thus, these investigations could improve the connection between river and its valley as well as the morphological activity of Mszanka River, below the Porębianka outlet. The rebuilt system would create wetted areas much more extensively then presently.

The discussed fragment of the Czarny Dunajec River is formed naturally but endangered by a limited transport of alluvial material. The river migrates aside, and this process slows down the channel incision. However, the process of steady growth of channel flow capacity is already observed in this section; the river may still flow in the braided channel. Thanks to the fens, it makes an excellent place for plant and animal habitats. The future discontinuation of the river outflows onto the valley could be a possible result.

Wetlands are regularly refreshed by flood events. Natural rivers continuously transform their channels, creating oxbow lakes; as a result, the nature enrichment develops. Moreover, they improve the retention conditions in river valleys. The man has always attempted at occupying these areas as their soil fertility makes them very attractive for cultivation. As long as wetlands and oxbow lakes are a result of fluvial processes existing in rivers, human should take into consideration the natural consequences, especially of river channel narrowing. The adequate processes of river channel transformation appear during average or high flows, while during designing processes of river training works mostly average flows are considered. This reflects in long term on river incision.

It is much easier to remedy environmental values in regions which are not urbanized and intensively cultivated or even not used at all. River training often destabilizes fluvial processes but in urbanized basins the whole hydrological, 
hydraulic and morphological system is transformed. Therefore, the correction and maintenance of environmental values can be undertaken easily in the presented sections of the Nida and Czarny Dunajec Rivers. The Vistula River is under intensive agricultural cultivation which makes it impossible to do complex restoration of the river in question. The rapid hydraulic structures in the referred reach of the Porębianka River had been adopted to prevent the intensive erosion which appeared after the technical regulation of the river in its upstream sections. To improve the wetland creation processes within the presented sections of regulated rivers, the upstream reaches should also be redesigned.

Acknowledgments Financial support for this study was provided by Polish National Science Centre within the projects:-project No N N305 186,537: The description of balanced mountain rivers and streams state on the basis on natural morphological parameters. Financial support of the Department of Hydraulics Engineering and Geotechnics. DS-3322/KIWIG/2013. Procesy hydrodynamiczne $w$ ciekach oraz procesy geodynamiczne powierzchniowych warstw zboczy na obszarze Polski Południowej (Hydrodynamical processes in rivers and geodynamical processes of surfaced layers hillsides in the region of South Poland); BM-4331 "Factors affecting the structure of the beetles (Coleopteria: Carabidae) in the floodplain of mountain rivers". 2012, and National Fund for Environmental Protection and Water Management. Renaturalization of the Nida river valley-The initial case study for the natural resources protection connected to the program "Nature 2,000" realisation plans. 2004. Vistula River activities were supported in part by the local authorities in town of Sandomierz. Authors would also send special thanks to Wiktoria Laszek, Piotr Madej, Paweł Muciek, Miłosz Nitka and Grzegorz Zawadzki who were indispensible in performed field works.

Open Access This chapter is distributed under the terms of the Creative Commons Attribution Noncommercial License, which permits any noncommercial use, distribution, and reproduction in any medium, provided the original author(s) and source are credited.

\section{References}

Bartnik W, Deńko S, Strużyński A, Zając T (2004a) Renaturyzacja obszaru zlewni NidyKoncepcja opracowana dla potrzeb ochrony zasobów przyrodniczych w związku z planami realizacji programu "NATURA 2000" (Renaturalization of Nida River basin — Concept created for protecting of the natural sources in connection to the Nature 2000 Program). Monograph, Drukrol s.c., Kraków (in Polish)

Bartnik W, Deńko S, Strużyński A, Zając T, Zawada M (2004b) Wstępna koncepcja renaturyzacji rzeki Nidy na odcinku delty środkowej (The initial concept of restoring the Nida River on the middle delta reach), Przegląd Naukowy, Inżynieria i Kształtowanie Środowiska, Rocznik XIII, Warszawa, zesz spec 30:220-230 (in Polish)

Bartnik W, Deńko S, Strużyński A, Zając T, Zawada M (2004b) Analiza warunków przyrodniczych i ocena potrzeb renaturyzacji rzeki Nidy na odcinku delty środkowej (Analysis of natural conditions and assesment of restoration needs of the Nida River on the middle delta reach). Przegląd Naukowy, Inżynieria i Kształtowanie Środowiska, Rocznik XIII, Warszawa, Zeszyty Specjalne 30:209-219 in Polish

Bartnik W, Książek L (2007) River and mountain streams training works under the hydrodynamic balance conditions. Infrastruct Ecol Rural Areas 4(2):15-26 
Bartnik W, Majewski W, Łapuszek M, Ratomski J (2007) The estimation of hydrodynamical balance of the lower Dunajec below hydro-energy power plant. Infrastruct Ecol Rural Areas 4 (1):21-37

Bartnik W, Książek L (2011) Identyfikacja przyczyn powodzi w 2010 roku na Wiśle w rejonie Sandomierza (Identification of the causes of flooding in 2010, on the Vistula River in the region of Sandomierz). Starzec-Wiśniewska, Bazan S (eds) Zagadnienia ochrony przeciwpowodziowej Zapobieganie wystąpieniu strat i łagodzenie skutków żywiołu w relacji z zagadnieniami zagospodarowania przesterzennego (Issues of flood protection and prospects for development of inland waterways). The regional water management board Gliwice-Kraków-Wrocław, pp 40-48 (in Polish)

Bartnik W, Książek L, Leja M, Wyrębek M, Strutyński M (2011) Evaluation of morphological changes of the Vistula river channel in Sandomierz after the flood in 2010. In: Sobota J (ed) 15th International conference on transport and sedimentation of solid particles, UP we Wrocławiu, pp 223-232

Bartnik W, Zając T, Strużyński A, Bobka A, Wyskiel G (2013) Wykonanie inwentaryzacji i waloryzacji środowiskowo przyrodniczej dla projektu - „Zrównoważony rozwój gospodarczy zlewni rzeki Nidy w związku z obszarami Natura 2000" wraz z dokumentacją przedprojektową do stadium decyzji o środowiskowych uwarunkowaniach zgody na realizację przedsięwzięcia etap I z III. Regional Board of Water Management. Dev. Kraków. manuscript (in Polish)

Church M (1992) Channel morphology and typology. In: Carlow P, Petts GE (eds) The Rivers Handbook. Blackwell Sci, Malden, Mass, pp 126-143

Faustini JM, Jones JA (2003) Influence of large woody debris on channel morphology and dynamics in steep, boulder-rich mountain streams, western Cascades. Or Elsevier Geomorphol 51:187-205

Gorczyca E, Krzemień K, Łyp M (2011) Contemporary trends in the Białka River channel development in the Western Carpathians, Geographia Polonica, 84. Speciall Issue Part 2:39-53

Kitanidis PK, Kennedy JF (1984) Secondary current and river-meander formation. J Fluid Mech 144:217-229

Kłonowska-Olejnik M, Radecki-Pawlik A (2000) Zróżnicowanie mikrosiedliskowe makrobezkręgowców dennych w obrębie łach korytowych potoku górskiego o dnie żwirowym (Micro-habitat diversification of bottom macrozoobenthos in the gravel bars of mountain streams). XVIII Zjazd Hydrobiologów Polskich (XVIII Association of Polish hydrobiologists). Białystok (In Polish)

Kopka W (1998) Badania modelowe zapór sortujących i dozujących rumowisko wleczone (Modeling of bedload transportation within sorting and dosing dams). PH.D. thesis. manuscript (In Polish)

Korpak J (2007) The influence of river training on mountain channel changes (Polish Carpathian Mountains). Elsevier Geomorphol 92(2007):166-181

Korpak J, Krzemień K., Radecki-Pawlik A (2009)Wpływ budowli regulacyjnych i poboru rumowiska na koryta rzek i potoków górskich - wybrane przykłady z rzek karpackich (The influence of hydraulic structures and bedload exploitation on the channels of mountain streamschosen examples from the Carpathians). Gospodarka Wodna, Warszawa, Sigma-Not 7:274-281 (in Polish

Krzemień K (1976) Współczesna dynamika koryta potoku Konina w Gorcach (Current dynamics of the Konina Stream riverbed). Folia Geogr Ser Geogr-Physica 7:87-122 (In Polish with English summary)

Krzemeń K (1984) Współczesne zmiany modelowania koryt potoków górskich w Gorcach. (Contemporary changes in mountains riverbed modeling in Gorce Mountains) Zeszyty Naukowe UJ. Prace Geograficzne 59:83-96

Książek L, Michalik A (2002) Some aspects of mountain river bed degradation, 11th Interernation Conference on "Transport and sedimentation of solid particles". Zeszyty Naukowe Akademii Rolniczej we Wrocławiu 438:73-82 
Książek L., Michalik A., Nowak J., Połoska-Wróbel A., 2010, Evaluation of hydrodynamic conditions changes on The Smolnik Stream, Infrastructure and Ecology of Rural Areas, 8/1, 93-104, in Polish with English summary

Leopold LB, Wolman MG (1957) River channel patterns - braided, meandering and straight. US Geol Surv Prof Pap 282B:39-85

Leopold LB, Wolman MG (1960) River Meanders. Bull Geol Soc Am 71:769-794

Łajczak A (2006a) Regulacja rzeki a zagrożenie powodziowe, na przykładzie Wisły między Skoczowem i Puławami (River training vs. flood exposure. The example of the river Vistula between Skoczów and Puławy, Poland). Infrastruktura i Ekologia Terenów Wiejskich. 2006/ 4 (1):197-215 (In Polish with English summary)

Łajczak A (2006b) Regulacja rzeki a zagrożenie powodziowe, na przykładzie Nidy (River training vs. flood exposure. The example of the river Nida, Poland). Infrastruktura i Ekologia Terenów Wiejskich 4(1): 217-133 (in Polish with English summary)

Łajczak A (2014) Zmiany w zagrożeniu powodziowym spowodowane regulacją rzeki na przykładzie doliny przedgórskiego biegu Wisły — stan aktualny i możliwości poprawy sytuacji (Changes in the risk of flooding due to river regulation on the example of the Vistula valley foreland-current status and scope for improvement). Scientific Conference Geomorfologia stosowana-Zastosowanie metod badań geomorfologicznych w inżynierii i kształtowaniu środowiska. 4-6 VI 2014. Warsaw University of Life Sciences-SGGW, manuscript (in Polish)

Maciejewski M, Ostojski MS, Walczykiewicz T (eds) (2011) Dorzecze Wisły. Monografia powodzi. Maj czerwiec 2010 (Wistula Watershed. The monograph of the flood. May June 2010). IMGW, Warszawa 236 (in Polish)

Michalik A, Bartnik W, Książek L, Goc A (1999) Zmiany koryta potoku Mszanka wywołane wezbraniami w latach 1995-1997 (changes in Mszanka stream riverbed caused by 1995-1997 freshets), Konferencja Naukowa "Bezpieczeństwo i trwałość budowli wodnych". Zeszyty Naukowe Akademii Rolniczej we Wrocławiu 363 (in Polish)

Plesiński K, Janas M, Radecki-Pawlik A (2013) Analysis of hydraulic parameters in near rapid hydraulic structure (RHS) in Porębianka Stream in Gorce Mountains. Acta Scientiarum Polonorum Formatio Circumiectus 12(1):101-114

Radecki-Pawlik A, Świderska K, Plesiński K (2010) Diversification of hydraulic parameters in near rapid hydraulic structures (RHS). Infrastruct Ecol Rural Areas 1:25-38

Radecki-Pawlik A (2011) Hydromorfologia rzek i potoków górskich (Hydro-morphology of the mountain rivers and streams), Wydawnictwo Uniwersytetu Rolniczego w Krakowie, Kraków, pp. 288 (in Polish)

Radecki-Pawlik A, Wieczorek M, Plesiński K (2011) Diversification of hydrodynamic parameters in close by woody debris. Acta Scientiarum Polonorum Formatio Circumiectus 10(2):35-46

Radecki-Pawlik A (2013) On using artificial rapid hydraulic structures (RHS) within mountain stream channels: some exploitation and hydraulic problems. In: Rowinski R (ed) Experimental and computational solutions of hydraulic problems. GeoPlanet: earth and planetary sciences. Springer, Berlin, pp 101-118. doi:10.1007/978-3-642-30209-1_17

Rhoads BL, Welford MR (1991) Initiation of river meandering. Prog Phys Geogr 15(2):127-156

Rosgen DL (1994) A classification of natural rivers. Catena 22:169-199

Strużyński A (2006) Skutki powodzi roztopowej w roku 2006 w uregulowanym odcinku delty śródlądowej rzeki Nidy (Consequences of the spring flood in 2006 on the regulated part of middle delta in the Nida River). Infrastruktura i Ekologia Terenów Wiejskich, Komisja Technicznej Infrastruktury Wsi PAN/o Kraków, 4/1 - monograph, ISSN 1732-5587, pp 235-247 (in Polish with English summary)

Strużyński A (2011) Flood protection in high valued river ecosystem - middle delta system of the Nida river. Electron J Pol Agr Univ 14(2), Wydawnictwo Akademii Rolniczej we Wroclawiu, ISSN 1505-0297, http://www.ejpau.media.pl/

Strużyński A, Wyrębek M, Strutyński M, Kulesza K (2011) 2011, Cross-Section Changes in the Lower Part of a Mountain River After the Flood in Spring 2010, as Presented by Means of 
CCHE2D Program. Exp Methods Hydraul Res Geoplanet: Earth Planet Sci 1:287-297. doi:10. 1007/978-3-642-17475-9_21

Strużyński A, Kulesza K, Strutyński M (2013) Bed Stability as a parameter describing the hydromorphological balance of a Mountain river. In: Rowinski P (ed) Experimental and computational solutions of hydraulic problems. GeoPlanet: earth and planetary sciences. Springer, Berlin, pp 249-251. doi:10.1007/978-3-642-30209-1_17

Strużyński A (2014) Ocena stanu oraz identyfikacja zaburzeń procesów fluwialnych w korytach rzek karpackich (Identification of the current state and fluvial processes disturbances in channels of Carpathian rivers). Acta Sci Pol Formatio Circumiectus 12(2):77-89 (in Polish with English summary, graphs and tables)

Wyżga B, Zawiejska $\mathbf{J}$ (2005) Wood storage in a wide mountain river: case study of the Czarny Dunajec. Polish Carpathians. Earth Surf Process Landforms 30:1475-1494

Wyżga B, Zawiejska J, Radecki-Pawlik A (2008) Określenie wielkości wcięcia si0119 rzek i jego wpływ na hydraulikę przepływów wezbraniowych—przykłady z rzek karpackich. Land Anal 9:402-405

Wyżga B, Zawiejska J, Radecki-Pawlik A (2009) Zróżnicowanie uziarnienia osadów korytowych rzeki górskiej przekształconej przez regulację koryta i eksploatację żwirów. Prace i Studia Geograficzne 44:195-203

Wyżga B, Hajdukiewicz H, Radecki-Pawlik A, Zawiejska J (2010a) Eksploatacja osadów z koryt rzek górskich — skutki środowiskowe i procedury oceny. Gospodarka Wodna, Warszawa, Sigma-Not 6:243-249

Wyżga B, Zawiejska J, Radecki-Pawlik A, Amirowicz A (2010b) A method for the assessment of hydromorphological river quality and its application to the Czarny Dunajec River, Polish Carpathians. Cultural landscapes of river valleys, University of Agriculture in Krakow 